\title{
Improving Critical Thinking Skills Using Problem Based Learning on the Media Flash Card
}

\author{
E. Erma ${ }^{1, a^{*}}$, Henny Dewi Koeswanti ${ }^{1, b}$, Sri Giarti $1^{1, c}$ \\ ${ }^{1}$ Department of Primary Teacher Education, Satya Wacana Christian University, Salatiga, Central Java, Indonesia \\ Jl. Diponegoro No.52-60, Salatiga, 50711 Indonesia \\ 2920115109@student.uksw.edu \\ ${ }^{*}$ Corresponding Author
}

How to Cite : Erma, E., Koeswanti, H., D., Giarti, S. (2019). Improving Critical Thinking Skills Using Problem Based Learning on the Media Flash Card. International Journal for Educational and Vocational Studies, 1 (6), 619-622

\section{ARTICLE HISTORY}

Received: 3 July 2019

Revised: 5 August 2019

Accepted: 12 September 2019

\section{KEYWORDS}

Critical Thinking Skills; Problem Based Learning;

Flash Card;

\section{ABSTRACT}

The purpose of this study is to improve students' critical thinking skills using the Problem Based Learning model aided by flash card media. The research method used is a class action research method. The subjects of the study were the 5th grade students of SD St. Theresia Massudirini 77 with 40 students. The results of observations in the pre-cycle that the critical thinking skills of students in the category are quite critical (15\%). Based on these problems, the researchers made improvements to the classroom action research, using the Problem Based Learning model aided by Flash Card media. The results showed that the critical thinking skills of students in the quite critical category were $(32.5 \%)$ in the first cycle and during the second cycle increased to $(75 \%)$.

This is an open access article under the CC-BY-SA license.

\section{INTRODUCTION}

The curriculum is holistic where knowledge, skills and values (values) are integrated with information needs in competency-based curriculum. The 2013 curriculum is a curriculum that was developed to prepare students to face future challenges, including technological development, future competencies that emphasize communication skills, critical thinking skills, as well as anticipating social phenomena (drugs, corruption), and public asumi about education that emphasizes on cognitive aspects and lacking in character (Trianto in Taubany, 2017: 3). The application of the 2013 curriculum uses a scientific approach which includes activities to ask, observe, reason, try and form networks and integrated thematic learning approaches that integrate subject content into the themes that have been applied (Rusman, 2017: 4). Regarding this, the government expects teachers to implement learning based on High Order Thinking Skills (HOTS), 4 C (Creative Thinking, Critical Thinking, Communicative, and Collaborative). One of the most important skills to improve in learning is critical thinking skills. Critical thinking skills According to Neolaka (2019: 75) is the skill to think at a complex level and use the process of analysis and evaluation. Neolaka further emphasized that critical thinking involves inductive thinking skills such as recognizing relationships, analyzing open problems, determining cause and effect, making conclusions and calculating relevant data. The skill of deductive thinking involves the ability to solve problems that are spatial, logical syllogism and distinguish between facts and opinions. Indicators of critical thinking skills according to Kuswana (2012: 198), include:

1) identifying the focus of the problem, questions and conclusions, (2) analyzing arguments, (3) asking and answering questions, (4) identifying decisions and handling according to reason, ( 5) observing and evaluating observational reports, (6) concluding and evaluating decisions, (7) considering reasons without allowing uncertainty and doubt, (8) combining other abilities and regulating in making and maintaining decisions.

The learning model that is possible for learning in the 2013 curriculum is Problem Based Learning. According to Wedyawati \& Lisa (2019: 147) PBL models are characterized by the use of real life problems as something students must learn to practice and improve critical thinking skills as well as problem solving, as well as gain knowledge of important concepts. Meanwhile, 
according to Malinda (2019: 24) learning models that involve students with real problems that match their interests and concerns, so motivation and curiosity become reminders. Thus students can be expected to develop ways of thinking and higher skills. Based on the definitions above, it can be concluded that the Problem Based Learning model is a learning model that involves students actively to improve and foster Christian thinking skills in solving or solving a problem. The effectiveness of the problem based learning model in improving students' critical thinking skills can be seen in research conducted by Rahayu, Sapri \& Alexon (2016) entitled "The Implementation of Problem Based Learning (PBL) Learning Models to Improve Critical Thinking Skills and Student Learning Achievement" concluded that there is an increase in students' critical thinking who learn with the Problem Based Learning (PBL) model each cycle; 2) An increase in student achievement with the Problem Based Learning (PBL) model, and make learning more effective. Then the research conducted by Zakiyah, Suryandari, \& Wahyudi (2016) entitled "Increasing Critical Thinking Skills through Problem Based Learning (PBL) Learning Model in Natural Sciences Learning About the Style of Class V Students at SD Negeri 1 Gebangsari Academic Year 2016/2017" The results showed that: (1) the application of the Problem Based Learning (PBL) learning model is carried out by the steps of: (a) identify the main problem, (b) make a problem solving plan, (c) carry out an investigation to solve the problem, (d) report the results of the investigation, (e) analyze the problem solving process, (2) apply the Problem Based Learning (PBL) learning model ) can improve students' critical thinking skills, (3) the application of the Problem Based Learning learning model can improve science learning outcomes.

Based on the study of the theory and the results of the research above, it illustrates that the Problem Based Learning model can improve students' critical thinking skills in the learning process. But the reality, based on observations at SD St. Theresia Marsudirini 77 Salatiga during learning, teachers use more cooperative and conventional learning models, wherein with these models students have not been given the opportunity to develop critical thinking skills because all the knowledge to the results obtained is the teacher's predictable direction. So that students' critical thinking skills are low at $15 \%$ of 40 students.

Based on the explanation above, research will be conducted using a problem based learning model with the help of flash card learning media in order to improve the critical thinking skills of students at SD St. Theresia Marsudirini 77 with the title "Improving Critical Thinking Skills Using Problem Based Learning Models Assisted by Thematic Class V Flash Card Learning Media".

\section{METHODS}

This research was conducted at SD St. Theresia Massudirini 77 Salatiga. This study aims to improve students' critical thinking skills. The research subjects are students in grade V SD St. Theresia Massudirini 77 salatiga totaling 40 students. While this type of research is classroom action research. Classroom action research in this study uses the Kemmis \& Mc.Taggart model which consists of four steps, namely designing action plans (planning), implementing actions, observing, reflecting.

Data collection techniques using observation techniques, questionnaires and documentation. Observation technique is used to determine teacher performance in the learning process. The questionnaire used was a closed questionnaire, which was used to determine the level of critical thinking skills of students in each cycle. While the documentation is used to obtain a list of student names. Data analysis uses reference guidelines developed by. Masidjo (1995: 153) can be seen in table 1.

Table 1. Assessment of Benchmark Reference Type I

\begin{tabular}{cc}
\hline Percentage & Criteria \\
\hline $90-100 \%$ & Very critical \\
\hline $80-89 \%$ & Critical \\
\hline $65-79 \%$ & Critical enough \\
\hline $55-64 \%$ & Less critical \\
\hline$<55 \%$ & Very less critical \\
\hline
\end{tabular}

\section{RESULTS AND DISCUSSION}

Table 2 shows the results of the first cycle of action using a problem based learning model assisted by flash card media.

Table 2. Critical Thinking Skills of Cycle I Students Class V SD St.Theresia Massudirini 77 Salatiga Semester I Academic Year 2019/2020

\begin{tabular}{cccc}
\hline Critical Thinking Level & Category & Frequency & Percentage \\
\hline $90-100$ & Very critical & 0 & $0 \%$ \\
\hline $80-89$ & Critical & 0 & $0 \%$ \\
\hline $65-79$ & Critical enough & 13 & $32.5 \%$ \\
\hline $55-64$ & Less critical & 12 & $30 \%$ \\
\hline$<55$ & Very less critical & 15 & $37.5 \%$ \\
\hline & & 40 & $100 \%$ \\
\hline
\end{tabular}

Based on the results in table 2, cycle 1 shows that the level of critical thinking skills of students is from 40 students with quite critical categories of 13 students with a percentage of $32.5 \%$, students with less critical criteria as many as 12 students with a percentage of $30 \%$ and students with very less critical criteria as much as 27 students. Based on the category of critical thinking skills it can be seen that the critical thinking skills of fifth grade students in the first cycle are quite critical. 
After carrying out the learning process in the first cycle, the researcher and the observer reflect on the learning process that must be improved because it is not appropriate to achieve the established performance indicators. Table 3 below shows the results of the second cycle.

Table 3. Critical Thinking Skills of Cycle II Students Class V SD St.Theresia Massudirini 77 Salatiga Semester I Academic Year 2019/2020

\begin{tabular}{cccc}
\hline $\begin{array}{c}\text { Critical Thinking } \\
\text { Level }\end{array}$ & Category & Frequency & Percentage \\
\hline $90-100$ & Very critical & 0 & $0 \%$ \\
\hline $80-89$ & Critical & 2 & $5 \%$ \\
\hline $65-79$ & Critical enough & 30 & $75 \%$ \\
\hline $55-64$ & Less critical & 7 & $17.5 \%$ \\
\hline$<55$ & Very less critical & 1 & $2.5 \%$ \\
\hline & Total & 40 & $100 \%$ \\
\hline
\end{tabular}

In table 3 the second phase of learning cycle shows that students' critical thinking skills are from 40 students with critical criteria of 2 students, students with quite critical categories are 30 students, students with less critical categories are 7 students, while students with very less critical level categories as many as 1 student. While the average value of students' critical thinking skills is $72 \%$. Based on the results of the analysis that has been done, the following will be presented categories of critical thinking skills of students in pre-cycle, cycle I, and cycle II with a percentage of success rate of $70 \%$ in the critical enough category in accordance with the agreement of teachers and researchers. This comparative analysis forms the presentation of data in the form of a comparison of students' critical thinking skills starting from the pre cycle, cycle I and cycle II. The results obtained in this comparative result, will be compared with the specified work indicators.

Table 4. Comparison of Critical Thinking Skills Pre Cycle, Cycle I and Cycle II

\begin{tabular}{|c|c|c|c|c|c|c|}
\hline \multirow[t]{2}{*}{ Level of Critical Thinking Skills } & \multicolumn{2}{|c|}{ Pre Cycle } & \multicolumn{2}{|c|}{ Cycle I } & \multicolumn{2}{|c|}{ Cycle II } \\
\hline & $\mathrm{F}$ & $\%$ & $\mathrm{~F}$ & $\%$ & $\mathrm{~F}$ & $\%$ \\
\hline Very critical & 0 & $0 \%$ & 0 & $0 \%$ & 0 & $0 \%$ \\
\hline Critical & 0 & $0 \%$ & 0 & $0 \%$ & 2 & $5 \%$ \\
\hline Critical enough & 6 & $15 \%$ & 13 & $32.5 \%$ & 30 & $75 \%$ \\
\hline Less critical & 7 & $17.5 \%$ & 12 & $30 \%$ & 7 & $17.5 \%$ \\
\hline Very less critical & 27 & $67.5 \%$ & 15 & $37.5 \%$ & 1 & $2.5 \%$ \\
\hline Total & 40 & $100 \%$ & 40 & 100 & 40 & $100 \%$ \\
\hline
\end{tabular}

Table 4 is a comparison of increasing critical thinking skills of fifth grade students of SDTTheresia Massudirini 77 Salatiga in the pre-cycle, cycle I and cycle II stages after using the problem based learning model with the help of flash card media in the learning process. Table 1.5 shows that an increase in students' critical thinking skills in each cycle is classically. From this table it is known that in the pre cycle the critical thinking skills of students are still in the very less critical category, where the level of student skills is $67.5 \%$ while students who are classified as quite critical are only 15 percent. However, in the first cycle there was an increase in students' critical thinking skills, namely the level of critical thinking skills of students in the quite critical category of $32.5 \%$. After the learning process in Cycle I was repaired in Cycle II, there was a much better improvement where students' critical thinking skills in the critical enough category increased to $75 \%$.

Based on the results of research that has been carried out, it is known that an increase in students' critical thinking skills in the learning activities of cycle I and cycle II in the application of problem based learning models assisted by flash card media. In the pre cycle the critical thinking skills of students in the category were quite critical by $15 \%$, after the learning process using the problem based learning model assisted by flash card media the critical thinking skills of students began to increase in the first cycle by $17.5 \%$ to $32.5 \%$, then after the improvement of the learning process in the cycle II an increase of $42.5 \%$ and became $75 \%$. The success of the problem based learning model assisted by the flash card media in improving critical thinking skills is also in line with Sri Rahayu (2017) that the Problem Based Learning model can improve students' critical thinking skills. Learning through the Problem Based Learning model can improve students' critical thinking skills because they are triggered to continue to be active in the learning process so that their enthusiasm grows by itself. Unconsciously they began to ask questions and answers, discuss each other, refute the arguments when discussing to solve problems, collect data in the learning process, and think of all the possibilities that exist from the material to conclude learning material so that their critical thinking skills develop and improve in the process learning.

\section{CONCLUSION}

Based on the results of the research that has been done, it can be concluded: (1) The steps of the Problem Based Learning model with the help of the Flash Card media can improve the critical thinking skills of fifth grade students of SD St.Theresia Massudirini 77 Salatiga in the 2019/2020 school year. (2) The application of the Problem Based Learning model with Flash Card media can improve the critical thinking skills of fifth grade students of SD St.Theresia Massudirini 77 Salatiga in the academic year $2019 / 2020$ by $32.5 \%$ (13 students) in the first cycle increased to $75 \%$ (30 students) in cycle II. 


\section{REFERENCES}

Azhar, A. (2010). Media Pembelajaran. Jakarta: Pt Raja Grafindo Persada.

Chatib, M. (2011). Gurunya Manusia. Bandung: Mizan Pustaka.

Kuswana, W. S. (2012). Taksonomi Kognitif Perkembangan Ragam Berfikir. Bandung: Remaja Rosdakarya.

Lisa, N. W. (2019). Pembelajaran Ipa Di Sekolah Dasar. Yogyakarta: Budi Utama.

Masidjo. (1995). Penilaian pencapaian hasil belajar siswa di sekolah. Yogyakarta: Kanisus.

Neolaka, A. (2019). Isu-isu Kritis Pendidikan: Utama dan Tetap Penting Namun Terabaikan. Jakarta: Prenadamedia Group

Malinda. (2019). Ptk Guru Matematika (Penelitian Tindakan Kelas): Penerapan Pembelajaran Kontekstual Pada Kelas Matematika Pokok Materi Ruang Dimensi Tiga Di Sma. Malinda.

Rusman. (2017). Belajar \& Pembelajaran: Berorientasi Standar Proses Pendidikan. Jakarta: Prenada Media.

Siti, Z., K., C,. (2016). Peningkatan Keterampilan Berpikir Kritis Melalui Model Pembelajaran Problem Based Learning (Pbl) Pada Pembelajaran Ipa Tentang Gaya Siswa Kelas V Sd Negeri 1 Gebangsari Tahun Ajaran 2016/2017. Kalam Cendekia, $231-237$.

Sri Rahayu, J. S. (2017). Penerapan Model Problem Based Learning (Pbl) Untuk Meningkatkanketerampilan Berpikir Kritis Dan Prestasi Belajar Siswa(Studi Pada Mata Pelajaran Ipa Kelas V Pada Sdn Gugus Ii Raflesia Talang Empatkabupaten Bengkulu Tengah. Diadik: Jurnal Ilmiah Teknologi Pendidikan, 98-110.

Suyanto, Y. N. (N.D.). Enerapan Model Problem-Based Learning Untuk Meningkatkan Keterampilan Berpikir Kritis Dan Hasil Belajar Siswa.

Taubany, T. I. (2017). Desain Pengembangan Kurikulum 2013 Di Madrasah. Kencana.

Windura, S. (2010). Memory Champin @ School: Rahasia Mengingat Materi Pelajaran Apa Saja. Jakarta: Gramedia. 